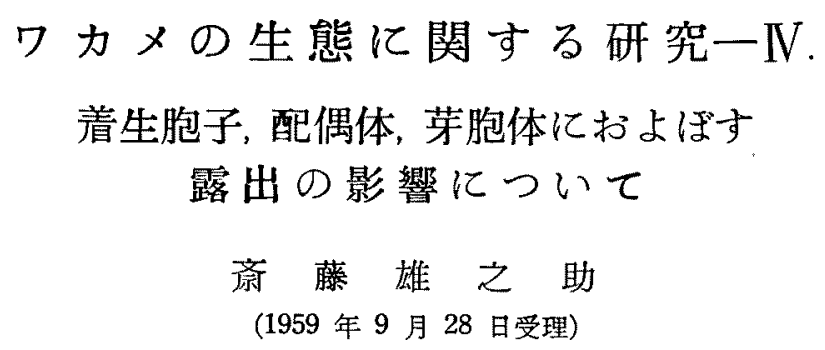

\begin{abstract}
AN ECOLOGICAL STUDY OF UNDARIA PINNATIFIDA SUR.-IV. ON THE INFLUENCE OF DESICCATION UPON THE RESTING ZOOSPORES, THE GAMETOPHYTES AND THE YOUNG SPOROPHYTES.
\end{abstract}

\title{
Yunosuke SAITo*
}

For the purpose to test its ability to stand to desiccation, the resting zoospores, the gametophytes of various growing stages, and the young sporophytes of Undaria pinnatifida were respectively exposed to the air of various humidity $(45,60.7,84$ and $100 \%)$ for various duration $(15,30,60,150$ and $180 \mathrm{~min}$.) at different air temperature.

After the necessary treatment they were immersed again into the normal sea water and then cultured for two or four days when their vitality or survival rate, growth rate and condition of health were examined and estimated under microscopical observations.

The results obtained were summarized as follows:

(1) When they were well dried in the air the resting zoospores, all cells of the gametophytes and the young sporophytes were shrivelled and died with the appearance like 'plasmolysis' in 5 6 minutes without regard to temperature or humidity of the atmosphere.

(2) The resting zoospores were more sensitive to desiccation than gametophytes and the young sporophytes (Table 1,2). In the case of gametophytes, those which were growing actively were more sensitive than those in resting stage (Table $3-A, B$ ).

(3) The resting zoospores, the gametophytes and the sporophytes could alive in the air of $100 \%$ humidity for long time, but in the air of lower humidity than $70.4 \%$ the resting zoospores were fatally affected in about 30 minutes and the gametophytes and the young sporophytes were affected in respectively 1 and 3 hours (Table $1 \sim 4$ ).

However the time which needs for desiccation of the materials varied with the temperature, that is to say, the temperature were higher, the time were shorter. Besides, the time varied whether they were cultured purely or not, i.e. it took much times when the glass slides were contaminated with other organisms such as diatoms etc.

近年, ワカメ增殖の目的を一層効果的ならしめるため胞子付けした石材の投入，胞子付け網の岩礁への沈 設，遠い処からの種苗移殖などが盛んに行なわれるようになつた。ところで，これらの作業に当つては操作 中, 着生したワカメの胞子, 配偶体, 芽胞体が露出して, 乾燥することがある。そこでワカメの着生胞子, 配偶体，芽胞体が乾燥によつて受ける影響の如何を明らかにすることは，これらの技術を一層安全確奏にす るために重要な点であると考えられる。

着生直後のワカメ胞子の乾燥による影響については，既に愛知罪水試尾張分場の報告》があるが，著者は 温度と湿度条件を明らかにして，ワカメの着生胞子，配偶体，芽胞体の乾燥によつて受ける影響を実䮖した ので，今までに得られた二三丨の結果について報告する。

本文に入るに先立ち，終始御指尊下さつた東大助教授新崎盛酷，種々御助言下さつた東海区水研須藤俊造

* 東宗大学農学部附属水産実踰所 (Fish. Lab. Fac. Agr. Tokyo Univ., Shimmaiko, Aichi Pref., Japan). 
の両氏に深䞡なる感謝の意を表する。

\section{実 験 方 法}

1958 年 6 月, 1959 年 4 月に愛知紧知多半島豊浜叮地先㧍よび常滑市地先より採集したワカメより陰干 し法により放出させた游走子をスライドガラスに着生させ, 着生直後,またはこれを培童して配偶体, 芽胞体 の発生をみた後,随時にスライドを水中よりとり出して振つて水切りし，褧面は吸取程で拭つて水を去つた後

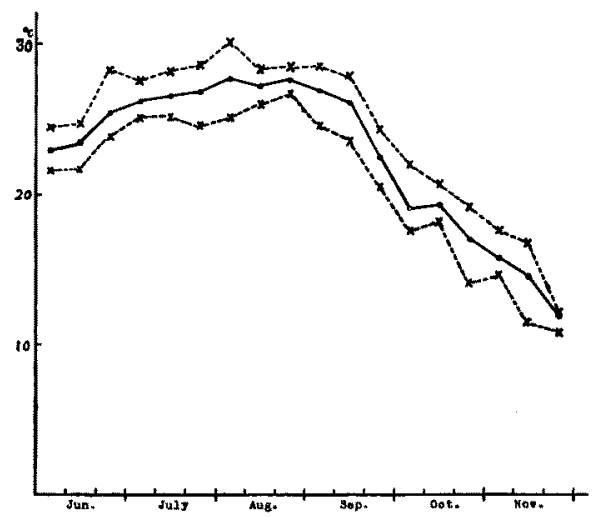

Fig. 1. Water temperature of culture vessel. (1958)

- average in each decade. $\times \cdots \times$ max. and min. in each decade. これを硫酸を用いて湿度を一定させた desiccator 内に 入れて, 気中に露出した。これを一定時間後に desiccator よりとり出して, 成可く速やが検鏡して生死判 断を行ない，海水中に5つし，さらに2 日〜をたは数日 後に険鏡して，露出させないで培盖した対照と比較し た。実験中，普通 desiccator は直射日光を避けた，日 中で大体 1,000lux の明るさのところに扰き，また直射 日光の影響を見るためには，直射日光を受ける（空ガラ ス，拈よび desiccator のガラスを通して） 10,000 lux 以上の明るさのところに和いた。

乾燥の影響を表方すには海水中に移してからの発芽, 生長, 生残の割合の相違をるつてしたが，着生胞子，配 偶体では $10 \times 12$, 芽胞体では $4 \times 12$ の顕微鏡 10 視野 の平均值を用いた。また，実䮖期間中の室内気温，水温 (午前 10 時测定) は Fig. 1 のごとくであつた。

\section{実 験 結 果}

\section{1. 着生直後の胞子の受ける影響}

胞子海水をスライドを底に教いた容器中に入れ，1時間後にスライドをとり出して胞子の着生を確認し， 数回水洗後, 前記のごとく水切りして湿度がそれぞれちが 5 desiccator 中に入れ，一定時間後海水に移し 2 日後または 4 日後に検鏡した。その結果はTable 1-A,B に示した。発芽，生長を表わすには，球状とな

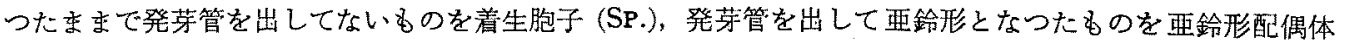
(D. B. G.)，発芽管の先端に新生細胞が形成されたときは細胞数 1 の配偶体 (C. N. 1) として区別して测定し た。また，生死の判別は細胞が腿色して黄緑色乃至無色となつたるのは死んだるのと判断した。

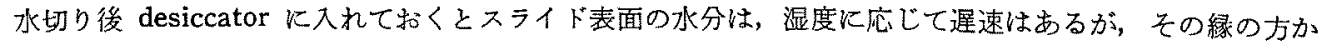
ら次第に蒸発してなくなるが，飽和蒸気中（湿度 $100 \%$ ）では数時間位では水分の変化は全く見られない。 露出後 15 分では，湿度 $84.0 \%$ のものはスライドの縁が全面積の $1 / 8$ 位に当る程度, 70.4\%では, 84.0 $\%$ ののと同じ位，60.7\%では 1/6 位，45.0\%では1/4 位また 30 分ではそれぞれ 1/4，1/4，1/3，1/2 位に当る面積が水分をうしなつて，スライドは乾燥したように見えた。垁験した温度の範囲では，同じ湿度 での温度によるスライド表面の乾燥速度に相違が見られなかつた。

着生胞子の受けた剔響は表に示したごとく，湿度 $100 \%$ では影響は少ないが，84.0\% で急に影響が現か れ，以下 $70.4 \% ， 60.7 \% ， 45.0 \%$ では，いずれも影響が現われているが， $45.0 \%$ で 15 分間，70.4\%， $60.7 \%, 45.0 \%$ で 30 分間の露出ではその影響が莍しかつた。な括，同じ気温では湿度の低い程，また同じ 湿度では気温の高い程, な海水にうつしたときの海水水温の高い程, また露出時間の長い程, 乾燥の影響 は大きく現われ，胞子は死んだり，発芽しなからたりまたは後の生長がすくれた。しかし，いずれの場合 もスライド全面一様に影響を受けたのではなく、スライドの部分によつて影響されすが甚だしく異なり，完 全に乾燥した部分は胞子は死減し，水分の残つた部分の胞子は全く影響がないなど，部分的に異つていた。 
Table 1-A. Effect of exposure to the air of various humidity upon the resting zoospores of Undaria pinnatifida.

\begin{tabular}{|c|c|c|c|c|c|c|c|c|}
\hline \multirow{3}{*}{ Humidity } & \multirow{3}{*}{$\begin{array}{l}\text { Time } \\
\text { of exp. }\end{array}$} & \multirow{3}{*}{$\frac{\text { Start }}{\text { SP. }}$} & \multicolumn{4}{|c|}{ Germination rate } & \multicolumn{2}{|c|}{ Survival rate } \\
\hline & & & \multicolumn{2}{|c|}{ after 2 days } & \multicolumn{2}{|c|}{ after 4 days } & \multirow{2}{*}{ start } & \multirow{2}{*}{$\begin{array}{l}\text { after } \\
4 \text { days }\end{array}$} \\
\hline & & & SP. & D.B. G. & C.N. 1 & 2 & & \\
\hline Contl. & 0 & $100 \%$ & $8.6^{\%}$ & $91.4^{\%}$ & $96.7^{\%}$ & $3.3^{\%}$ & $100 \%$ & $100 \%$ \\
\hline $100^{\%}$ & $\begin{array}{l}15 \mathrm{~min} . \\
30 \mathrm{~min} .\end{array}$ & 100 & $\begin{array}{l}32.6 \\
24.8\end{array}$ & $\begin{array}{l}67.4 \\
75.2\end{array}$ & $\begin{array}{l}97.5 \\
97.8\end{array}$ & $\begin{array}{l}2.5 \\
2.2 \\
\end{array}$ & $\begin{array}{l}100 \\
100\end{array}$ & $\begin{array}{l}100 \\
100\end{array}$ \\
\hline 84.0 & $\begin{array}{l}15 " \prime \\
30 " \prime\end{array}$ & 100 & $\begin{array}{l}61.9 \\
87.2\end{array}$ & $\begin{array}{l}38.1 \\
12.8\end{array}$ & $\begin{array}{l}100 \\
100\end{array}$ & $\begin{array}{l}0 \\
0\end{array}$ & $\begin{array}{l}100 \\
100\end{array}$ & $\begin{array}{l}37.8 \\
31.7\end{array}$ \\
\hline 70.4 & $\begin{array}{l}15 " \prime \\
30 "\end{array}$ & 100 & $\begin{array}{l}65.9 \\
100\end{array}$ & $\begin{array}{c}34.1 \\
0\end{array}$ & 98.2 & 1.8 & $\begin{array}{l}100 \\
100\end{array}$ & $\begin{array}{c}32.2 \\
0\end{array}$ \\
\hline 60.7 & $\begin{array}{l}15 " \prime \\
30 " \prime\end{array}$ & 100 & $\begin{array}{l}84.0 \\
100\end{array}$ & $\begin{array}{c}16.0 \\
0\end{array}$ & 100 & 0 & $\begin{array}{l}100 \\
100\end{array}$ & $\begin{array}{c}38.0 \\
0\end{array}$ \\
\hline 45.0 & $\begin{array}{l}15 " \prime \\
30 "\end{array}$ & 100 & $\begin{array}{c}71.7 \\
100\end{array}$ & $\begin{array}{c}28.3 \\
0\end{array}$ & 100 & 0 & $\begin{array}{l}100 \\
100\end{array}$ & $\begin{array}{c}28.0 \\
0\end{array}$ \\
\hline
\end{tabular}

Zoospores were shed. at 10: 45 a.m. Apr. 15. 1959.

Desiccation

Time Apr. 15.

Air temp.

11: 45

12: 00

12: 15

Water temp.

$15.4^{\circ} \mathrm{C}$.

16.2

16.2

SP.....resting zoospore (round type).

14.5

D.B. G. .... dumb bell typed germling.

C.N. $\cdots$ cellnumber of gametophyte.

Table 1-B. Effect of exposure to the air of various humidity upon the resting zoospores of $U$. pinnatifida.

\begin{tabular}{|c|c|c|c|c|c|c|c|c|}
\hline \multirow{3}{*}{ Humidity } & \multirow{3}{*}{$\begin{array}{l}\text { Time } \\
\text { of exp. }\end{array}$} & \multirow{3}{*}{$\begin{array}{c}\text { Start } \\
\text { SP. }\end{array}$} & \multicolumn{4}{|c|}{ Germination rate } & \multicolumn{2}{|c|}{ Survival rate } \\
\hline & & & \multicolumn{2}{|c|}{ after 2 days } & \multicolumn{2}{|c|}{ after 4 days } & \multirow{2}{*}{ start } & \multirow{2}{*}{$\begin{array}{c}\text { after } \\
4 \text { days }\end{array}$} \\
\hline & & & SP. & D.B. G. & C.N. 1 & 2 & & \\
\hline Contl. & 0 & 100 & $24.6^{\%}$ & $75.6^{\%}$ & $81.7^{\%}$ & $18.3^{\%}$ & $100 \%$ & $80.7^{\%}$ \\
\hline $100^{\%}$ & $\begin{array}{l}15 \mathrm{~min} . \\
30 \mathrm{~min} .\end{array}$ & 100 & $\begin{array}{r}32.1 \\
4.9\end{array}$ & $\begin{array}{l}67.9 \\
95.1\end{array}$ & $\begin{array}{l}71.8 \\
73.1\end{array}$ & $\begin{array}{l}28.2 \\
26.9\end{array}$ & $\begin{array}{l}100 \\
100\end{array}$ & $\begin{array}{c}74.5 \\
100\end{array}$ \\
\hline 84.0 & $\begin{array}{l}15 " \prime \\
30 "\end{array}$ & 100 & $\begin{array}{l}72.6 \\
65.2\end{array}$ & $\begin{array}{l}27.4 \\
34.8\end{array}$ & $\begin{array}{l}61.7 \\
74.4\end{array}$ & $\begin{array}{l}38.3 \\
25.6\end{array}$ & $\begin{array}{l}100 \\
100\end{array}$ & $\begin{array}{l}45.2 \\
33.9\end{array}$ \\
\hline 70.4 & $\begin{array}{l}15 " \prime \\
30 "\end{array}$ & 100 & $\begin{array}{l}63.4 \\
88.6\end{array}$ & $\begin{array}{l}36.6 \\
11.4\end{array}$ & $\begin{array}{l}79.4 \\
51.8\end{array}$ & $\begin{array}{l}20.6 \\
48.2\end{array}$ & $\begin{array}{l}100 \\
100\end{array}$ & $\begin{array}{r}34.3 \\
3.5\end{array}$ \\
\hline 60.7 & $\begin{array}{l}15 " \prime \\
30 "\end{array}$ & 100 & $\begin{array}{l}45.2 \\
95.9\end{array}$ & $\begin{array}{r}54.8 \\
4.1\end{array}$ & $\begin{array}{l}77.6 \\
100\end{array}$ & $\begin{array}{c}22.4 \\
0\end{array}$ & $\begin{array}{l}100 \\
100\end{array}$ & $\begin{array}{r}35.1 \\
1.6\end{array}$ \\
\hline 45.0 & $\begin{array}{l}15 " \prime \\
30 " \prime\end{array}$ & 100 & $\begin{array}{l}94.9 \\
87.0\end{array}$ & $\begin{array}{r}5.1 \\
13.0\end{array}$ & $\begin{array}{l}83.8 \\
79.1\end{array}$ & $\begin{array}{l}16.2 \\
20.9\end{array}$ & $\begin{array}{l}100 \\
100\end{array}$ & $\begin{array}{l}4.8 \\
1.7\end{array}$ \\
\hline
\end{tabular}

Zoospores were shed. at 11: 40 a.m. June 17. 1958.

Desiccation June 17.

Time

$12: 45$
$24.7^{\circ} \mathrm{C}$.

Air temp.

13: 00

13: 15

Water temp.

$23.9^{\circ} \mathrm{C}$. $\quad 19.9$

24.7

19.9 


\section{2，配偶体の受ける影響}

游走子の着生後 3,4 日培美して亜鈴形に癹芽した配偶体，および約 1 ケ月培荃して $5,6 〜 12,13$ 細胞に 成長した配偶体などについて，1 と同様に実騟した。また 5，6１2，13 細胞に成長した配偶体については， 水道水にて冷却しつつ低水温（19.9 21.6 $\left.{ }^{\circ} \mathrm{C}\right)$ で培養して，休眠に入つていないるのと，室内水温（23.9〜

Table 2-A. Effect of exposure upon the gametophytes cultured for 3 days.

\begin{tabular}{|c|c|c|c|c|c|c|c|c|c|c|c|}
\hline \multirow{3}{*}{ Humidity } & \multirow{3}{*}{$\begin{array}{l}\text { Time } \\
\text { of exp. }\end{array}$} & \multicolumn{7}{|c|}{ Germination rate } & \multicolumn{3}{|c|}{ Survival rate } \\
\hline & & \multicolumn{2}{|c|}{ start } & \multicolumn{2}{|c|}{ after 2 days } & \multicolumn{3}{|c|}{ after 4 days } & \multirow{2}{*}{ start } & \multirow{2}{*}{$\begin{array}{c}\text { after } \\
2 \text { days }\end{array}$} & \multirow{2}{*}{$\begin{array}{c}\text { after } \\
4 \text { days }\end{array}$} \\
\hline & & SP. & D.B. G. & C.N. 1 & 2 & C.N. 1 & 2 & 3 & & & \\
\hline Contl. & 0 & $19.3^{\%}$ & $80.7^{\%}$ & $89.3^{\%}$ & $10.7^{\%}$ & 13.0 & $\begin{array}{r}\% \\
40.7\end{array}$ & $46.3^{\%}$ & $100^{\%}$ & $100 \%$ & $98.6^{\%}$ \\
\hline $100 \%$ & $\begin{array}{l}15 \mathrm{~min} . \\
30 \mathrm{~min} .\end{array}$ & 19.3 & 80.7 & $\begin{array}{l}90.2 \\
88.1\end{array}$ & $\begin{array}{r}9.8 \\
11.9\end{array}$ & $\begin{array}{l}5.4 \\
8.0\end{array}$ & $\begin{array}{l}49.3 \\
45.5\end{array}$ & $\begin{array}{l}45.3 \\
46.5\end{array}$ & $\begin{array}{l}100 \\
100\end{array}$ & $\begin{array}{l}100 \\
83.5\end{array}$ & $\begin{array}{l}96.8 \\
75.8\end{array}$ \\
\hline 84.0 & $15 " \prime$ & 19.3 & 80.7 & $\begin{array}{l}86.1 \\
81.3\end{array}$ & $\begin{array}{l}13.9 \\
18.7\end{array}$ & $\begin{array}{l}1.5 \\
2.0\end{array}$ & $\begin{array}{l}38.4 \\
42.9\end{array}$ & $\begin{array}{l}60.1 \\
55.1\end{array}$ & $\begin{array}{l}100 \\
100\end{array}$ & $\begin{array}{l}71.3 \\
55.4\end{array}$ & $\begin{array}{l}69.6 \\
50.3\end{array}$ \\
\hline 70.4 & $15 " \prime$ & 19.3 & 80.7 & $\begin{array}{l}85.2 \\
91.3\end{array}$ & $\begin{array}{r}14.8 \\
8.7\end{array}$ & & & & $\begin{array}{l}100 \\
100\end{array}$ & $\begin{array}{l}64.7 \\
33.3\end{array}$ & \\
\hline 60.7 & $\begin{array}{ll}15 & \prime \prime \\
30 & \prime \prime\end{array}$ & 19.3 & 80.7 & $\begin{array}{l}85.7 \\
79.0\end{array}$ & $\begin{array}{l}14.3 \\
21.0\end{array}$ & & & & $\begin{array}{l}100 \\
100\end{array}$ & $\begin{array}{l}50.7 \\
20.4\end{array}$ & \\
\hline 45.0 & $\begin{array}{l}15 " \prime \\
30 "\end{array}$ & 19.3 & 80.7 & $\begin{array}{l}84.2 \\
87.5\end{array}$ & $\begin{array}{l}15.8 \\
12.5\end{array}$ & & & & $\begin{array}{l}100 \\
100\end{array}$ & $\begin{array}{r}53.5 \\
5.7\end{array}$ & \\
\hline
\end{tabular}

Zoospores were shed. Apr. 15. 1959.

$\begin{array}{llll}\text { Desiccation } & \text { Apr. } 18 . & & \\ \text { Time } & 10: 10 & 10: 25 & 10: 40 \\ \text { Air temp. } & 15.7^{\circ} \mathrm{C} . & - & 15.7\end{array}$

Water temp. $\quad 15.6^{\circ} \mathrm{C}$. $\quad 15.0 \quad 15.0$

Table 2-B. Effect of exposure upon the gametophytes, which were cultured for 4 days.

\begin{tabular}{|c|c|c|c|c|c|c|c|c|c|c|c|}
\hline \multirow{3}{*}{ Humidity } & \multirow{3}{*}{$\begin{array}{l}\text { Time } \\
\text { of exp. }\end{array}$} & \multicolumn{7}{|c|}{ Germination rate } & \multicolumn{3}{|c|}{ Survival rate } \\
\hline & & \multicolumn{2}{|c|}{ start } & \multicolumn{2}{|c|}{ after 2 days } & \multicolumn{3}{|c|}{ after 4 days } & \multirow[b]{2}{*}{ start } & \multirow{2}{*}{$\begin{array}{c}\text { after } \\
2 \text { days }\end{array}$} & \multirow{2}{*}{$\begin{array}{c}\text { after } \\
4 \text { days }\end{array}$} \\
\hline & & C.N. 1 & 2 & C.N. 1 & 2 & C.N. 1 & 2 & 3 & & & \\
\hline Contl. & 0 & $61.1^{\%}$ & $38.9^{\%}$ & $60.9^{\%}$ & $39.1^{\%}$ & 28.3 & 51.7 & 20.0 & $100^{\%}$ & $100 \%$ & $100 \%$ \\
\hline $100 \%$ & $\begin{array}{l}15 \mathrm{~min} . \\
30 \mathrm{~min} .\end{array}$ & 61.1 & $38 \cdot 9$ & $\begin{array}{l}73.0 \\
61.2\end{array}$ & $\begin{array}{l}27.0 \\
38.8\end{array}$ & $\begin{array}{r}10.9 \\
1.1\end{array}$ & $\begin{array}{l}80.9 \\
91.0\end{array}$ & $\begin{array}{l}8.2 \\
7.9\end{array}$ & $\begin{array}{l}100 \\
100\end{array}$ & $\begin{array}{l}100 \\
79.8\end{array}$ & $\begin{array}{l}100 \\
77.2\end{array}$ \\
\hline 84.0 & $15 " \prime$ & 61.1 & 38.9 & $\begin{array}{l}52.6 \\
71.9\end{array}$ & $\begin{array}{l}47.4 \\
28.1\end{array}$ & $\begin{array}{r}4.8 \\
12.5\end{array}$ & $\begin{array}{l}85.2 \\
76.1\end{array}$ & $\begin{array}{l}10.0 \\
11.4\end{array}$ & $\begin{array}{l}100 \\
100\end{array}$ & $\begin{array}{l}34.8 \\
30.4\end{array}$ & $\begin{array}{l}23.7 \\
20.6\end{array}$ \\
\hline 70.4 & $15 "$ & 61.1 & 38.9 & $\begin{array}{l}56.3 \\
87.0\end{array}$ & $\begin{array}{l}43.7 \\
13.0\end{array}$ & $\begin{array}{r}16.7 \\
4.6\end{array}$ & $\begin{array}{l}69.8 \\
73.0\end{array}$ & $\begin{array}{l}13.5 \\
22.4\end{array}$ & $\begin{array}{l}100 \\
100\end{array}$ & $\begin{array}{l}42.8 \\
25.8\end{array}$ & $\begin{array}{l}36.9 \\
25.8\end{array}$ \\
\hline 60.7 & $\begin{array}{l}15 " \prime \\
30 " \prime\end{array}$ & 61.1 & 38.9 & $\begin{array}{l}63.8 \\
86.1\end{array}$ & $\begin{array}{l}36.2 \\
13.9\end{array}$ & $\begin{array}{l}5.5 \\
0\end{array}$ & $\begin{array}{l}80.1 \\
100\end{array}$ & $\begin{array}{c}14.4 \\
0\end{array}$ & $\begin{array}{l}100 \\
100\end{array}$ & $\begin{array}{l}35.3 \\
22.5\end{array}$ & $\begin{array}{l}28.5 \\
20.3\end{array}$ \\
\hline 45.0 & $\begin{array}{l}15 " \prime \\
30 "\end{array}$ & 61.1 & 38.9 & $\begin{array}{l}65.4 \\
100\end{array}$ & $\begin{array}{c}34.6 \\
0\end{array}$ & $\begin{array}{l}5.0 \\
0\end{array}$ & $\begin{array}{c}82.7 \\
0\end{array}$ & $\begin{array}{c}12.3 \\
0\end{array}$ & $\begin{array}{l}100 \\
100\end{array}$ & $\begin{array}{r}36: 0 \\
2.3\end{array}$ & $\begin{array}{c}19.3 \\
0\end{array}$ \\
\hline
\end{tabular}

Zoospores were shed. June 17, 1958.

Desiccation

Time

Air temp.

Water temp.
June 21 .

9: $45 \quad 10: 00 \quad 10: 15$

$24.6^{\circ} \mathrm{C} . \quad-\quad 24.6$

$23.9^{\circ} \mathrm{C}$. $\quad-\quad 23.9$ 
$26.8^{\circ} \mathrm{C}$ 位) で培盖して細胞が球状となり，細胞膜がやや肥厚して，いわゆる休眠状態になつたるのとにつ いて央験しだ”。そしてこれらについては，生長の割合と生残率について調べた。また低水温で培盖中であ つたすのを飽和水蒸気中に長時間露出して，その影䈉を調べた。それらの結果は Table 2,3 に示した。

発芽したばかりの亜鈴形配偶体の乾燥によつて受ける影響は，大体1 の場合と同じよ5にスライドの部分 によつて，乾燥の程度によつて死んだり，生長が扩くれたりしたが，着生直後の胞子より露出によつて受け

Table 3-A. Effect of exposure upon the growing gametophytes.

\begin{tabular}{|c|c|c|c|c|c|c|c|c|c|c|}
\hline \multirow{3}{*}{ Humidity } & \multirow{3}{*}{$\begin{array}{l}\text { Time } \\
\text { of exp. }\end{array}$} & \multicolumn{6}{|c|}{ Rate of living and dead gametophytes } & \multicolumn{3}{|c|}{ Survival rate } \\
\hline & & \multicolumn{2}{|c|}{ start } & \multicolumn{2}{|c|}{ after 2 days } & \multicolumn{2}{|c|}{ after 4 days } & \multirow{2}{*}{ start } & \multirow{2}{*}{$\begin{array}{c}\text { after } \\
2 \text { days }\end{array}$} & \multirow{2}{*}{$\begin{array}{c}\text { after } \\
4 \text { days }\end{array}$} \\
\hline & & living & dead & living & dead & living & dead & & & \\
\hline Contl. & $\mathbf{0}$ & $\begin{array}{l}100 \% \\
(1.6)\end{array}$ & $0 \%$ & $\begin{array}{c}100 \% \\
(1.6)\end{array}$ & $0 \%$ & $100 \%$ & $0 \%$ & $100 \%$ & $100 \%$ & 100 \\
\hline $100 \%$ & $\begin{array}{l}30 \mathrm{~min} . \\
60 \mathrm{~min} .\end{array}$ & $\begin{array}{l}100 \\
(2.0)\end{array}$ & 0 & $\begin{array}{c}100 \\
(2.1) \\
100 \\
(11.8)\end{array}$ & $\begin{array}{l}0 \\
0\end{array}$ & $\begin{array}{c}100 \\
(4.6) \\
100 \\
(14.9)\end{array}$ & $\begin{array}{l}0 \\
0\end{array}$ & $\begin{array}{l}100 \\
100\end{array}$ & $\begin{array}{l}100 \\
100\end{array}$ & $\begin{array}{l}100 \\
100\end{array}$ \\
\hline 70.4 & $\begin{array}{l}30 " \\
60 "\end{array}$ & $\begin{array}{l}100 \\
(2.4)\end{array}$ & 0 & $\begin{array}{c}100 \\
(12.1) \\
0\end{array}$ & $\begin{array}{r}0 \\
100\end{array}$ & $\begin{array}{c}100 \\
(13.4) \\
0\end{array}$ & $\begin{array}{r}0 \\
100\end{array}$ & $\begin{array}{l}100 \\
100\end{array}$ & $\begin{array}{r}100 \\
0\end{array}$ & $\begin{array}{r}100 \\
0\end{array}$ \\
\hline 45.0 & $\begin{array}{l}30 " \\
60 "\end{array}$ & $\begin{array}{l}100 \\
(1.7)\end{array}$ & 0 & $\begin{array}{c}67.7 \\
(14.6) \\
0\end{array}$ & $\begin{array}{l}32.3 \\
100\end{array}$ & $\begin{array}{c}77.8 \\
(23.9) \\
0\end{array}$ & $\begin{array}{l}22.2 \\
100\end{array}$ & $\begin{array}{l}100 \\
100\end{array}$ & $\begin{array}{c}67.7 \\
0\end{array}$ & $\begin{array}{c}57.8 \\
0\end{array}$ \\
\hline
\end{tabular}

Zoospores were shed. June 17. 1958.

Water temperature in culture vessel. $\quad 19.9 \sim 21.2^{\circ} \mathrm{C}$.

Desiccation

Time July 14 .

Air temp. 10: 25 10: 55 11: 25

Water temp.

$25.1^{\circ} \mathrm{C} . \quad 25.3 \quad 26.1$

Number in ( ) shows percentage of individual having dead cells.

Tabl 3-B. Effect of exposure upon the resting typed gametophytes with thickened cell wall.

\begin{tabular}{|c|c|c|c|c|c|c|c|c|c|c|}
\hline \multirow{3}{*}{ Humidity } & \multirow{3}{*}{$\begin{array}{l}\text { Time } \\
\text { of exp. }\end{array}$} & \multicolumn{6}{|c|}{ Rate of living and dead gametophytes } & \multicolumn{3}{|c|}{ Survival rate } \\
\hline & & \multicolumn{2}{|c|}{ start } & \multicolumn{2}{|c|}{ after 2 days } & \multicolumn{2}{|c|}{ after 4 days } & \multirow[b]{2}{*}{ start } & \multirow{2}{*}{$\begin{array}{c}\text { after } \\
2 \text { days }\end{array}$} & \multirow{2}{*}{$\begin{array}{l}\text { after } \\
4 \text { days }\end{array}$} \\
\hline & & living & dead & living & dead & living & dead & & & \\
\hline \multirow{2}{*}{100} & \multirow{2}{*}{$\begin{array}{l}30 \mathrm{~min} . \\
60 \mathrm{~min} .\end{array}$} & \multirow{2}{*}{$\begin{array}{c}\% \% \\
94.7 \\
(2.8)\end{array}$} & \multirow{2}{*}{$5.3^{\%}$} & \multirow{2}{*}{$\begin{array}{c}95.0 \% \\
(3.2) \\
98.0 \\
(9.5) \\
\end{array}$} & $5.0 \%$ & \multirow{2}{*}{$\begin{array}{c}100 \% \\
(2.9) \\
100 \\
(1.0) \\
\end{array}$} & \multirow[t]{2}{*}{$0 \%$} & $100 \%$ & \multirow{2}{*}{$\begin{array}{l}100 \% \\
100\end{array}$} & \multirow{2}{*}{$\begin{array}{l}100 \% \\
100\end{array}$} \\
\hline & & & & & 2.0 & & & 100 & & \\
\hline \multirow{2}{*}{70.4} & $30 "$ & \multirow{2}{*}{$\begin{array}{l}100 \\
(20.7)\end{array}$} & \multirow{2}{*}{0} & \multirow{2}{*}{$\begin{array}{c}99.1 \\
(22.2) \\
6.6 \\
(3.0) \\
\end{array}$} & 0.9 & \multirow{2}{*}{$\begin{array}{c}100 \\
(4.5) \\
14.5 \\
(9.6)\end{array}$} & 0 & 100 & 99.1 & 90.2 \\
\hline & $60 "$ & & & & 93.4 & & 85.5 & 100 & 6.6 & 4.5 \\
\hline \multirow{2}{*}{60.7} & $30 \prime$ & \multirow{2}{*}{$\begin{array}{l}97.7 \\
(3.1)\end{array}$} & \multirow{2}{*}{2.3} & \multirow{2}{*}{$\begin{array}{c}100 \\
(3.6) \\
10.0 \\
(0)\end{array}$} & 0 & \multirow{2}{*}{$\begin{array}{c}100 \\
(4.5) \\
0.6 \\
(0) \\
\end{array}$} & 0 & 100 & 99.4 & 98.5 \\
\hline & $60 "$ & & & & 90.0 & & 99.4 & 100 & 9.8 & 0.6 \\
\hline \multirow{2}{*}{45.0} & $30 "$ & \multirow{2}{*}{$\begin{array}{c}98.5 \\
(6.2)\end{array}$} & \multirow{2}{*}{1.5} & \multirow{2}{*}{$\begin{array}{c}89.8 \\
(12.6) \\
0.6 \\
(0.6) \\
\end{array}$} & 10.2 & $\begin{array}{l}100 \\
(12.9)\end{array}$ & 0 & 100 & 90.4 & 65.7 \\
\hline & $60 "$ & & & & 99.4 & 0 & 100 & 100 & 0.6 & 0 \\
\hline
\end{tabular}

Zoospores were shed. June 17. 1958.

Water temperature in culture vessel. $\quad 23.9 \sim 26.8^{\circ} \mathrm{C}$.

Desiccation

Time July 22 .

Air temp. 9: 25

Water temp.

$27.1^{\circ} \mathrm{C}$.

$26.8^{\circ} \mathrm{C}$.
9: 55

27.2

26.8
10: 25

27.6

26.8 
Table 3-C. Effect of exposure in the air of $100 \%$ for long time upon the gametophytes.

\begin{tabular}{|c|c|c|c|c|c|c|c|c|c|c|c|c|}
\hline \multirow{3}{*}{ No. } & \multirow{3}{*}{ Time of exp. } & \multicolumn{10}{|c|}{ Rate of living and dead gametophytes } & \multirow{3}{*}{\begin{tabular}{|c}
$\begin{array}{c}\text { Survival } \\
\text { rate }\end{array}$ \\
Sep. 18 \\
\end{tabular}} \\
\hline & & \multicolumn{2}{|c|}{$\begin{array}{r}\text { start. } \\
\text { Aug. } 7\end{array}$} & \multicolumn{2}{|c|}{ Aug. 11} & \multicolumn{2}{|c|}{ Aug. 16} & \multicolumn{2}{|c|}{ Aug. 20} & \multicolumn{2}{|c|}{ Sep. 18} & \\
\hline & & living & dead & living & dead & living & dead & living & dead & living & dead & \\
\hline I & $\begin{array}{l}\text { Aug. } 7 \sim \text { Aug. } 8 \\
1 \text { day }\end{array}$ & $100 \%$ & $0 \%$ & $\begin{array}{r}\% \\
100 \\
(0.6) \\
\end{array}$ & $0^{\%}$ & $100 \%$ & $0^{\%}$ & $\%$ & $\%$ & $\%$ & $\%$ & $100 \%$ \\
\hline II & $\begin{array}{l}\text { Aug. } 7 \text { days } \\
\text { Aug. } 12\end{array}$ & $\begin{array}{l}98.6 \\
(0.3)\end{array}$ & 1.4 & & & $\left|\begin{array}{c}77.8 \\
(21.2)\end{array}\right|$ & 22.2 & $\begin{array}{c}63.6 \\
(11.1)\end{array}$ & 36.4 & & & 81.2 \\
\hline III & $\begin{array}{l}\text { Aug. } 7 \sim \text { Aug. } 18 \\
\text { I1 days }\end{array}$ & $\begin{array}{l}99.8 \\
(5.5)\end{array}$ & 0.2 & & & & & $\begin{array}{c}52.1 \\
(15.3)\end{array}$ & 47.9 & & & 72.3 \\
\hline IV & $\begin{array}{l}\text { Aug. } 7 \text { Sep. } 8 \\
32 \text { days }\end{array}$ & $\begin{array}{l}100 \\
(2.8)\end{array}$ & 0 & & & & & & & $\begin{array}{l}57.7 \\
(24.6)\end{array}$ & 42.3 & 54.9 \\
\hline
\end{tabular}

Zoospores were shed. June 11. 1958.

Air temperature in exposure.
I . $26.1 \sim 26.2^{\circ} \mathrm{C}$.
II. $25.8 \sim 27.3^{\circ} \mathrm{C}$.
III. $25.8 \sim 28.2^{\circ} \mathrm{C}$.
IV. $25.4 \sim 29.1^{\circ} \mathrm{C}$.

る影響は少なかつた。

また，かなり成長した配偶体（る 6〜14 細胞位，9 2 5 細胞位) の場合も大体同様であつた。しかし， この場合は後述する芽胞体の場合にもいえることであるが，スライド上に繁殖した藍藻類，硅藻類の多少に よつてスライドの乾燥程度が異なり，これらの雑生物の多く着生した部分では水分が長く保たれるので，配

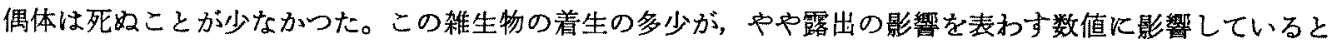

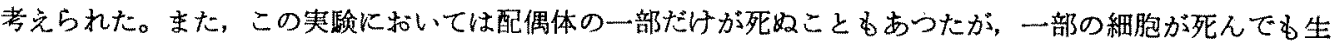
き残つた部分は，その後普通に成長し，成熟した。李た，休眠状態にない配偶体の方が，休眠状態にある配 偶体よりやや露出の影響を大きくうけるように思われたが前者の方が実験時の気・轻温の差が大きかつたの で,これが影響したのかる知れない。

※た, 飽和蒸気（湿度 100 \%) 中以長時間露出した実匬 では，海水にうつした後，容 器老水道水で冷却しつつ, 比 較的低温 $\left(21.2 \sim 23.2^{\circ} \mathrm{C}\right)$ で 培善したが, Table 3-C K 示すごとく，1日間の露出で は殆んど影響がなく，5日， 11 日, 32 日の露出では配偶 体個体の全細胞が死奴もの， あるいは一部の細胞が死ぬも のもあつた。そして 32 日閒 処理でも生き残つたるのは， その後順調に生育, 成熟して 11 月には芽胞体を生じた。

\section{3. 茅胞体の受ける影響}

芽胞体についても $1 ， 2$ と 同様に実験したが，その結果 は Table 4 に示した。この 場合，腿色して死んだと思わ れる細胞で称括われる部分が 茅胞体の体表面の $1 / 3$ 以下の

Table 4-A. Effect of exposure upon the young sporophytes.

\begin{tabular}{|c|c|c|c|c|c|c|c|c|}
\hline \multirow{3}{*}{ Humidity } & \multirow{3}{*}{\multicolumn{2}{|c|}{$\begin{array}{c}\text { Time } \\
\text { of exp. }\end{array}$}} & \multicolumn{4}{|c|}{$\begin{array}{l}\text { Rate of living and dead } \\
\text { young sporophytes }\end{array}$} & \multicolumn{2}{|c|}{ Survival rate } \\
\hline & & & \multicolumn{2}{|c|}{ start } & \multicolumn{2}{|c|}{ after 2 days } & \multirow[b]{2}{*}{ start } & \multirow{2}{*}{$\begin{array}{l}\text { after } \\
2 \text { days }\end{array}$} \\
\hline & & & living & dead & living & dead & & \\
\hline \multirow{2}{*}{100} & $30 n$ & & $\begin{array}{c}100 \\
(0.3)^{\%}\end{array}$ & & $\begin{array}{l}99.9 \% \\
(0.2)\end{array}$ & $0.1 \%$ & $10 \%$ & $99.9^{\%}$ \\
\hline & $60 n$ & $\min$. & $\begin{array}{c}100 \\
(2.6)\end{array}$ & 0 & $\begin{array}{l}99.6 \\
(2.5)\end{array}$ & 0.4 & 100 & 99.6 \\
\hline \multirow{2}{*}{84.0} & & & $\begin{array}{l}97.5 \\
(4.1)\end{array}$ & 2.5 & $\begin{array}{l}97.9 \\
(5.0)\end{array}$ & 2.1 & 100 & 100 \\
\hline & 60 & $"$ & $\begin{array}{c}94.9 \\
(5.6) \\
\end{array}$ & 5.1 & $\begin{array}{c}98.0 \\
(4.8)\end{array}$ & 2.0 & 100 & 100 \\
\hline \multirow{2}{*}{70.4} & 30 & & $\begin{array}{r}99.9 \\
(0)\end{array}$ & 0.1 & $\begin{array}{c}99.9 \\
(0)\end{array}$ & 0.1 & 100 & 100 \\
\hline & 60 & $"$ & $100(0)$ & 0 & $\begin{array}{r}100 \\
(7.3)\end{array}$ & 0 & 100 & 100 \\
\hline \multirow{2}{*}{60.7} & & & $\begin{array}{l}94.7 \\
(6.2)\end{array}$ & 5.3 & $\begin{array}{c}95.5 \\
(6.3)\end{array}$ & 4.5 & 100 & 90.8 \\
\hline & 60 & $"$ & $\begin{array}{c}99.5 \\
(3.3)\end{array}$ & 0.5 & $\begin{array}{c}97.6 \\
(1.8)\end{array}$ & 2.4 & 100 & 87.9 \\
\hline \multirow{2}{*}{45.0} & & & $\begin{array}{l}98.5 \\
(0.9)\end{array}$ & 1.5 & $\begin{array}{l}97.6 \\
(2.0)\end{array}$ & 2.4 & 100 & 83.9 \\
\hline & 60 & $"$. & $\begin{array}{l}95.0 \\
(8.4)\end{array}$ & 5.0 & $\begin{array}{l}97.5 \\
(5.8)\end{array}$ & 2.5 & 100 & 53.0 \\
\hline \multicolumn{3}{|c|}{ esiccatio } & $\begin{array}{l}11.0^{\circ} \\
15.9^{\circ} \\
15.3^{\circ}\end{array}$ & & $\begin{array}{l}1: 35 \\
6.8 \\
5.6\end{array}$ & $\begin{array}{l}12: 05 \\
16.9 \\
15.9\end{array}$ & & \\
\hline
\end{tabular}


Table 4-B. Effect of exposure upon the young sporophytes.

\begin{tabular}{|c|c|c|c|c|c|c|c|}
\hline \multirow{3}{*}{ Humidity } & \multirow{3}{*}{$\begin{array}{c}\text { Time } \\
\text { of exp. }\end{array}$} & \multicolumn{4}{|c|}{$\begin{array}{l}\text { Rate of living and dead } \\
\text { young sporophytes }\end{array}$} & \multicolumn{2}{|c|}{ Survival rate } \\
\hline & & \multicolumn{2}{|c|}{ start } & \multicolumn{2}{|c|}{ after 2 days } & \multirow{2}{*}{ start } & \multirow{2}{*}{$\begin{array}{l}\text { after } \\
2 \text { days }\end{array}$} \\
\hline & & living & dead & living & dead & & \\
\hline \multirow{2}{*}{$84.0^{\%}$} & \multirow{2}{*}{$\begin{array}{l}150 \mathrm{~min} \\
180 \mathrm{~min} .\end{array}$} & $\begin{array}{l}99.8 \% \\
(1.4)\end{array}$ & $0.2^{\%}$ & $\begin{array}{l}99.3 \% \\
(5.7)\end{array}$ & $0.7^{\%}$ & $100 \%$ & $97.0 \%$ \\
\hline & & $\begin{array}{c}98.5 \\
(1.5)\end{array}$ & 1.5 & $\begin{array}{l}87.5 \\
(5.5)\end{array}$ & 12.5 & 100 & 87.3 \\
\hline \multirow{2}{*}{70.4} & $150 "$ & $\begin{array}{l}100 \\
(0.6)\end{array}$ & 0 & $\begin{array}{l}90.9 \\
(4.9)\end{array}$ & 9.1 & 100 & 74.3 \\
\hline & $180 "$ & $\begin{array}{l}97.7 \\
(2.9)\end{array}$ & 2.3 & $\begin{array}{l}32.5 \\
(5.8)\end{array}$ & 67.5 & 100 & 26.8 \\
\hline \multirow{2}{*}{60.7} & $150 "$ & $\begin{array}{l}97.9 \\
(1.5)\end{array}$ & 2.1 & $\begin{array}{l}98.5 \\
(1.6)\end{array}$ & 1.5 & 100 & 85.0 \\
\hline & $180 "$ & $\begin{array}{l}100 \\
(0.2)\end{array}$ & 0 & $\begin{array}{l}67.0 \\
(6.8)\end{array}$ & 33.0 & 100 & 36.2 \\
\hline \multicolumn{8}{|c|}{ Desiccation } \\
\hline \multicolumn{2}{|c|}{ Time } & \multirow{2}{*}{\multicolumn{3}{|c|}{$11: 40$}} & $14: 10$ & \multicolumn{2}{|l|}{ 14: 40} \\
\hline \multicolumn{2}{|c|}{ Air temp. } & $13.6^{\circ} \mathrm{C}$. & & 14.6 & 14.7 & \multicolumn{2}{|l|}{14.7} \\
\hline \multicolumn{2}{|c|}{ Water temp. } & \multicolumn{2}{|c|}{$12.8^{\circ} \mathrm{C}$} & - & 13.4 & \multicolumn{2}{|l|}{13.6} \\
\hline
\end{tabular}

Table 4-C. Effect of exposure under direct rays of the sun upon the young sporophytes.

\begin{tabular}{|c|c|c|c|c|c|c|c|}
\hline \multirow{3}{*}{ Humidity } & \multirow{3}{*}{$\begin{array}{l}\text { Time } \\
\text { of exp. }\end{array}$} & \multicolumn{4}{|c|}{$\begin{array}{l}\text { Rate of living and dead } \\
\text { young sporophytes }\end{array}$} & \multicolumn{2}{|c|}{ Survival rate } \\
\hline & & \multicolumn{2}{|c|}{ start } & \multicolumn{2}{|c|}{ after 2 days } & \multirow{2}{*}{ start } & \multirow{2}{*}{$\begin{array}{l}\text { after } \\
2 \text { days }\end{array}$} \\
\hline & & living & dead & living & dead & & \\
\hline $100 \%$ & $30 \mathrm{~min}$. & $\begin{array}{c}97.5^{\%} \\
(5.0)\end{array}$ & $2.5^{\%}$ & $\begin{array}{c}100 \% \\
(2.5)\end{array}$ & $0 \%$ & $100 \%$ & $100 \%$ \\
\hline 84.0 & $30 "$ & $\begin{array}{l}99.3 \\
(5.7)\end{array}$ & 0.7 & $\begin{array}{l}10.0 \\
(2.5)\end{array}$ & 90.0 & 100 & 0.2 \\
\hline 70.4 & $30 "$ & $\begin{array}{l}90.9 \\
(4.9)\end{array}$ & 9.1 & $\begin{array}{l}17.4 \\
(5.2)\end{array}$ & 82.6 & 100 & 4.3 \\
\hline 60.7 & $30 " \prime$ & $\begin{array}{l}98.5 \\
(1.6)\end{array}$ & 1.5 & 0 & 100 & 100 & 0 \\
\hline 45.0 & $30 " \prime$ & $\begin{array}{l}98.6 \\
(1.4)\end{array}$ & 1.4 & 0 & 100 & 100 & 0 \\
\hline $\begin{array}{l}\text { Desi } \\
\text { Tim } \\
\text { Air } \\
\text { Wat }\end{array}$ & $\begin{array}{l}\text { ccation } \\
\text { temp. } \\
\text { er temp. }\end{array}$ & $\begin{array}{l}\text { Nov. } \\
13: 3 \\
20.2^{\circ} \\
14.7^{\circ}\end{array}$ & 19. & $\begin{array}{l}14: 05 \\
20.2 \\
16.9\end{array}$ & & & \\
\hline
\end{tabular}

場合は生に含め，1/3 以上の 場合は死として测定した。実 影に使用した芽胞体は，長さ 50 一 $700 \%$ 位注生長したもの であつた。

この実験沈いては，スラ イドに硅藻が繁殖したり，芽 胞体名密生していたり，かつ 低温での奏験であつたためか 水分が比较的よく保たれ，湿 度 $60.7 \%, 45.0 \%, 60$ 分露 出でも僅かに影篦が現かれた のみであつた。しかしこれ以 上長時間籍出した場合は， 84.0\%で 3 時間露出, 70.4\%， $60.7 \%$ で 2.5 時間露出で影 響があつた（Table 4-A, B)。 な怙，㴬日光下では空内 気温が $16^{\circ} \mathrm{C}$ であるのに desiccator 内の気温は $18.0^{\circ} \mathrm{C}$ となり，スライドは大体 20一 $21^{\circ} \mathrm{C}$ の温度となつたが，こ の場合は 15 分間の露出で湿 度 $100 \%$ の場合は水分が残り $84.0 \% ， 70.4 \%$ で一部に水 分が残つたのみで，他はほと んど乾き，30 分間では 100\% の場合のみが水分が僅か心残 つたのみで他は乾いてしまつ た (Table 4-C)。 第胞体をスライドよりはぎ とり，乾いたスライド上にの せて, 気温 $14^{\circ} \mathrm{C}$, 湿度 $65 \%$ の下で簬出したま検鏡して

細胞の変化を倠察したが，5分間では原形質分離悓られないが，6分後位から紐胞間に透明部を生じて原 形質分離を起し始め，10 分後には完全に原形質分離を起し，その後 20 分，30 分後に歹特に変化は見られ なかつた。そしてこれらを 10 分後， 20 分後，30 分後に水温 $11.2^{\circ} \mathrm{C}$ の海水にらつして培養し， 2 日後に 観察したが,すべて死んでいた。

\section{総括並びに考悉}

以、の結果を緿括すれば，露出した際の湿度，混度は䒴生地物の水分，およびワカメの狍偶体，芽胞体の 表面水分の消失に大きな影響をおよぼするのて，ワカメ配偶体，芽胞体は乾燥すれば外気の湿度，温度に余 り関倸なく，大体数分で原形質分離を起して露出後海水に移しても死んでしま5ょ5であつた。しかしなが 
らワカメの着生胞子, 配偶体, 芽胞体が乾燥されるまでの時間は露出中の湿度, 気温によつて異なり, 高温 ほど、また低湿度ほどその時間は短かかつた。また直射日光下では, これを避けた場合に比して着生地物お よび配偶体, 芽胞体の温度上䄯が激しく, 乾燥が早いので影響は大きい。さらには露出中の気温と, 海水に 移した時の水温との差も影響を与えているかも知れない。また着生直後の胞子と配偶体比発芽したもの，括 よび休眠状態にない配偶体と休眠状熊にある配偶体とでは，鞋燥によつて受ける影響度が異なり，それぞれ 前者の方が大きな影響を受けるようである。芽胞体と配偶体とは露出したときの温度が異なるので，乾燥に よる影響の大小は比較することはできないが，両者ともに同じ位の時間で原形質分離を起すことから考えて 大差はないのではないだららか。

ワカメ增，養殖作業の施行中にワカメの着生胞子，配偶体，芽胞体が露出されることはしばしばあること であるが，結局は露出時間を短かくし，值射日光をさけて乾燥しない上5留意すべきであると考える。特に 着生淔後の胞子は作業上露出されることが多いのに, 乾燥に対しては弱いので, 留意すべきであると考え る。また養殖のため種繩の移殖の時期は, 露出という面のみから考劣れば配偶体期, 芽胞体期のいずれでる

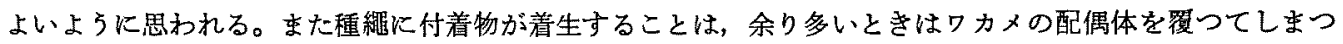
て，その成長を阻害することもあ万弓が，露出に祭しては，これによつて水分が保たれ，乾燥が倣くれるの で多少は佳藻その他の付着生物の着生はあつた方がよいこともあるように思5。さらに飽和水蒸気（湿度 100\%) 中での露出は, その影響が少なく, 高温でる配偶体はよく長時間の露出に耐えうるので, 移殖方法な どにおいて考慮すべき条件であろう。

要はワカメの着生胞子, 配偶体, 芽胞体の露出に耐え弓る時間は, 着生地物, 着生地物の表面の状態, 附 着生物の多宣执よび湿度, 温度によつて異なるので定め難いが, これらは着生地物が水分を失つて斡燥され れば数分にして死滅するので，着生地物が乾燥する限度は越えてはならないといいらるのではないだろう מ。

\section{文献}

1) 愛知県水試尾張分場：昭和 30 年度業務報告畫, (1956).

2) 斎藤雄之助：本誌, 22 (4), (1956).

3) 須藤俊造: 口頭発表, 日水学会高知大会, (1951).

4）水産庁調整二課： 浅海外海增殖事業括よび同事業効果調查報些書. 昭和 27〜32 年度, (1952 1957). 